\title{
The Stem Cell Marker Lgr5 Defines a Subset of Postmitotic Neurons in the Olfactory Bulb
}

\author{
Yiqun Yu, ${ }^{1,2,3 *}$ Andrew H. Moberly, ${ }^{2 *}$ Janardhan P. Bhattarai, ${ }^{2}$ Chen Duan, ${ }^{3}$ Qian Zheng, ${ }^{1}$ Fangqi Li, ${ }^{1}$ Hugh Huang, ${ }^{2}$ \\ William Olson, ${ }^{2}$ Wenqin Luo, ${ }^{2}$ Tieqiao Wen, ${ }^{1}$ Hongmeng $\mathrm{Yu},{ }^{3}$ and Minghong $\mathrm{Ma}^{2}$ \\ ${ }^{1}$ School of Life Sciences, Shanghai University, Shanghai, China 200444, ${ }^{2}$ Department of Neuroscience, University of Pennsylvania Perelman School of \\ Medicine, Philadelphia, Pennsylvania 19104, and ${ }^{3}$ Department of Otolaryngology, Eye, Ear, Nose and Throat Hospital, Shanghai Key Clinical Disciplines of \\ Otorhinolaryngology, Fudan University, Shanghai, China 200031
}

Lgr5, leucine-rich repeat-containing G-protein coupled receptor 5, is a bona fide biomarker for stem cells in multiple tissues. Lgr5 is also expressed in the brain, but the identities and properties of these Lgr5 ${ }^{+}$cells are still elusive. Using an Lgr5-EGFP reporter mouse line, we found that, from early development to adulthood, Lgr5 is highly expressed in the olfactory bulb (OB), an area with ongoing neurogenesis. Immunostaining with stem cell, glial, and neuronal markers reveals that Lgr5 does not label stem cells in the OB but instead labels a heterogeneous population of neurons with preference in certain subtypes. Patch-clamp recordings in OB slices reveal that Lgr5-EGFP ${ }^{+}$ cells fire action potentials and display spontaneous excitatory postsynaptic events, indicating that these neurons are integrated into $\mathrm{OB}$ circuits. Interestingly, R-spondin 3, a potential ligand of Lgr5, is also expressed in the adult OB. Collectively, our data indicate that Lgr5-expressing cells in the $\mathrm{OB}$ are fully differentiated neurons and imply distinct roles of Lgr5 and its ligand in postmitotic cells.

Key words: genetic tracing; Lgr5; olfactory bulb; periglomerular cells; short axon cells; stem cells

Significance Statement

Lgr5 (leucine-rich repeat-containing G-protein coupled receptor 5) is a bona fide stem cell marker in many body organs. Here we report that Lgr5 is also highly expressed in the olfactory bulb (OB), the first relay station in the brain for processing odor information and one of the few neural structures that undergo continuous neurogenesis. Surprisingly, Lgr 5 is not expressed in the $\mathrm{OB}$ stem cells, but instead in a few subtypes of terminally differentiated neurons, which are incorporated into the $\mathrm{OB}$ circuit. This study reveals that Lgr ${ }^{+}$cells in the brain represent a nonstem cell lineage, implying distinct roles of Lgr5 in postmitotic neurons.

\section{Introduction}

The maintenance and repair of many adult tissues depend on resident specialized stem cells, and specific molecular markers have been identified and used to characterize and track these stem cells. In recent years, Lgr5, leucine-rich repeat-containing G-protein-coupled receptor 5, has been established as an adult stem cell marker in small intestine and colon (Barker et al., 2007;

\footnotetext{
Received Feb. 21, 2017; revised July 31, 2017; accepted Aug. 14, 2017.

Author contributions: Y.Y., A.H.M., W.L., and M.M. designed research; Y.Y., A.H.M., J.P.B., C.D., Q.Z., F.L., and W.O. performed research; W.L., T.W., and H.Y. contributed unpublished reagents/analytic tools; Y.Y., A.H.M., J.P.B., H.H., and M.M. analyzed data; Y.Y., A.H.M., and M.M. wrote the paper.

This work was supported by the National Institute on Deafness and Other Communication Disorders and National Institutes of Health Grants R01DC011554 and R01DC006213 to M.M., and the Shanghai Eastern Scholar Program from Shanghai Municipal Education Commission to Y.Y.

The authors declare no competing financial interests.

*Y.Y. and A.H.M. contributed equally to this study.

Correspondence should be addressed to either of the following: Dr. Yiqun Yu, School of Life Sciences, Shanghai University, 333 Nanchen Road, Shanghai, China 200444, E-mail: Yiqun_Yu@shu.edu.cn; or Dr. Minghong Ma, 110 Johnson Pavilion, 3600 Hamilton Walk, Philadelphia, PA 19104. E-mail: minghong@upenn.edu.

DOI:10.1523/JNEUROSCI.0500-17.2017

Copyright $\odot 2017$ the authors $\quad 0270-6474 / 17 / 379403-12 \$ 15.00 / 0$
}

Tian et al., 2011), stomach (Barker et al., 2010; Leushacke et al., 2013), hair follicles (Jaks et al., 2008), kidney (Barker et al., 2012), mammary gland (de Visser et al., 2012; Plaks et al., 2013), and ovary (Ng et al., 2014; Sun et al., 2014). By binding R-spondins, secreted Wnt signaling agonists, Lgr5 mediates the Wnt pathway, which plays critical roles in embryonic development and adult cell genesis in various tissues (Carmon et al., 2011; Glinka et al., 2011; de Lau et al., 2011, 2014). Lgr5 also labels stem cells in sensory organs, such as the eye (Hirata-Tominaga et al., 2013), ear (Shi et al., 2012, 2013; Bramhall et al., 2014), tongue (Yee et al., 2013), and nose (Chen et al., 2014). Curiously, Lgr5 is expressed in several types of neurons, including the mouse retinal amacrine cells (Sukhdeo et al., 2014) and cerebellar granule neurons (Miller et al., 2014), suggesting a potential role of Lgr5 outside of epithelial stem cells.

Interestingly, Lgr5 is highly expressed in the olfactory bulb $(\mathrm{OB})$, the first relay station in the brain for processing odor information and one of the few neural structures that undergo adult neurogenesis (Ming and Song, 2011; Lepousez et al., 2015). Olfactory sensory neurons in the nose project their axons directly 
to the $\mathrm{OB}$ and form synapses with $\mathrm{OB}$ neurons in specialized structures called glomeruli. The OB projection neurons (mitral/ tufted cells) subsequently carry the information to the olfactory cortices. The $\mathrm{OB}$ can be divided into different layers from the surface to the center: the glomerular layer (GL), the external plexiform layer (EPL), the mitral cell layer (MCL), the internal plexiform layer (IPL), the granule cell layer (GCL), and the core region, which is continuous with the rostral migratory stream (RMS) from the subventricular zone (SVZ) (Lledo et al., 2008; Whitman and Greer, 2009). Each layer contains heterogeneous cells characterized by distinct morphologies, molecular markers, and firing patterns (McQuiston and Katz, 2001; Parrish-Aungst et al., 2007; Batista-Brito et al., 2008; Kiyokage et al., 2010; Kosaka and Kosaka, 2011). For instance, in the glomerular layer, the juxtaglomerular cells surrounding individual glomeruli are subdivided into three major types: the external tufted (ET) cells, periglomerular (PG) cells, and short axon (SA) cells, which display distinct electrophysiological properties. Despite high expression of $\operatorname{Lgr} 5$ in the OB, the identities and properties of Lgr $5^{+}$cells in the $\mathrm{OB}$ are unknown.

In this study, we investigated identities of Lgr5 ${ }^{+}$cells in the OB using an Lgr5-EGFP reporter mouse line as well as genetic lineage tracing of cells expressing Lgr5 at different developmental stages. Immunostaining and in situ hybridization with a number of molecular markers reveal that Lgr5-EGFP ${ }^{+}$cells in the OB are not stem cells but rather are fully differentiated neurons with preference in certain subtypes. Genetic lineage tracing confirms that Lgr5-EGFP ${ }^{+}$cells do not give rise to other OB cells in adult animals. Patch-clamp recordings confirm that these neurons fire action potentials and display spontaneous excitatory postsynaptic events. Furthermore, R-spondin 3, one of Lgr5 ligands, is also expressed in the adult OB. Bath perfusion of R-spondin 3 does not acutely change the electrophysiological properties of Lgr5$\mathrm{EGFP}^{+}$cells, suggesting that they may function in a chronic manner. These data indicate that Lgr5-EGFP ${ }^{+}$cells in the OB represent a nonstem cell lineage, implying distinct roles of Lgr5 and its ligand in postmitotic neurons.

\section{Materials and Methods}

Animals. Genetically targeted heterozygous Lgr5-EGFP-IRES-cre/ERT2 mice (stock \#008875; harboring a "knock-in" allele that abolishes Lgr5 gene function and expresses EGFP and CreERT2 fusion protein from the Lgr5 promoter/enhancer elements) and Rosa26-floxed STOP-tdTomato mice (stock \#007909; a cre reporter strain with a loxP-flanked STOP cassette prevents transcription of the downstream red fluorescent protein) were purchased from the The Jackson Laboratory. Both male and female mice were used in this study, and the data were grouped together because no sex difference was evident. The procedures of animal handling and tissue harvesting were approved by the University of Pennsylvania institutional animal care and use committee.

For genetic lineage tracing, Lgr5-EGFP-IRES-cre/ERT2 mice were crossed with Rosa26-tdTomato mice. To induce the expression of the reporter gene, a single dose of tamoxifen $(0.22 \mathrm{mg} / \mathrm{g}$ body weight, Sigma $)$ was injected intraperitoneally at the age of 6 weeks. Mice were then killed at different time points after tamoxifen induction.

For BrdU staining, mice were injected with one dose of BrdU (50 $\mu \mathrm{g} / \mathrm{g}$ body weight, Sigma) at the age of 4 weeks and killed $2 \mathrm{~h}$ after injection. For unilateral naris closure, a brief cauterization $(<1 \mathrm{~s})$ with a cauterizer (Fine Science Tools) was performed on one nostril at postnatal day 1 (P1), and the mice were examined 1 month later. Only mice with complete closure on the operated side were used for further analysis.

Immunohistochemistry. Mice were deeply anesthetized by intraperitoneal injection of ketamine-xylazine (200 and $15 \mathrm{mg} / \mathrm{kg}$ body weight, respectively) before decapitation. The heads were fixed in $4 \%$ PFA (Sigma) overnight at $4^{\circ} \mathrm{C}$ and infiltrated in a series of sucrose solutions before being embedded in OCT. The frozen tissues were cut into $20 \mu \mathrm{m}$ coronal sections on a cryostat. After antigen retrieval in a $95^{\circ} \mathrm{C}$ water bath for $10 \mathrm{~min}$ (followed by $10 \mathrm{~min}$ in $2 \mathrm{~N} \mathrm{HCl}$ at $37^{\circ} \mathrm{C}$ for $\mathrm{BrdU}$ detection), the tissue sections were blocked for $60 \mathrm{~min}$ in $0.3 \%$ Triton X-100 in PBS with $5 \% \mathrm{BSA}$ and then incubated at $4^{\circ} \mathrm{C}$ with the primary antibodies overnight. The primary antibodies included goat anti-Sox2 (sex determining region Y-box2; 1:100, Santa Cruz Biotechnology), mouse antiKi67 (1:100, BD Biosciences), mouse anti-Nestin (neuroectodermal stem cell marker; 1:200, Millipore), mouse anti-BrdU (1:1000, Millipore), goat anti-GFAP (1:1000, Sigma), mouse anti-NeuN (1:500, Millipore), rabbit anti-TH (1:500, Millipore), goat anti-glutamic acid decarboxylase 65 (GAD65; 1:100, Abcam), mouse anti-calbindin (CB; 1:500, Sigma), mouse anti-calretinin (CR; 1:500, Millipore), sheep anti-5T4 oncofetal trophoblast glycoprotein (1:200, R\&D Systems), goat anti-doublecortin (DCX) (1:200, Santa Cruz Biotechnology), or mouse anti-Lgr5 (1:100, OriGene). The secondary antibodies (1:300, ThermoFisher Scientific) included donkey anti-goat-568, donkey anti-mouse-568, donkey antirabbit-568, donkey anti-rabbit-647, donkey anti-sheep-647, donkey anti-mouse-488, and donkey anti-goat-633. Tissues were mounted in Vectashield (Vector Laboratories). Fluorescent images were taken under a SP5/Leica confocal microscope with LAS AF Lite software.

Patch-clamp recording in olfactory bulb slices. Adult Lgr5-EGFP-IREScre/ERT2 mice (4-12 weeks old, either gender) were deeply anesthetized with ketamine-xylazine (200 and $15 \mathrm{mg} / \mathrm{kg}$ body weight, respectively) and decapitated. The olfactory bulbs were dissected out and immediately placed in ice-cold Ringer's solution containing the following (in $\mathrm{mm}$ ): $124 \mathrm{NaCl}, 3 \mathrm{KCl}, 1.3 \mathrm{MgSO}_{4}, 2 \mathrm{CaCl}_{2}, 26 \mathrm{NaHCO}_{3}, 1.25 \mathrm{NaH}_{2} \mathrm{PO}_{4}, 5.5$ glucose, and 4.47 sucrose; osmolality $\sim 305 \mathrm{mOsm}$ and $\mathrm{pH} \sim 7.4$, bubbled with $95 \% \mathrm{O}_{2}-5 \% \mathrm{CO}_{2}$. Horizontal slices (300 $\mu \mathrm{m}$ thick) were cut using a Leica VT $1200 \mathrm{~S}$ vibratome. Slices were incubated in oxygenated Ringer's solution for $30 \mathrm{~min}$ at room temperature before use. For recordings, slices were transferred to a recording chamber and continuously perfused with oxygenated Ringer's solution. EGFP-labeled cells were visualized using an Olympus $40 \times$ water-immersion objective on a BX51WI upright microscope equipped with epifluorescence and differential interference contrast optics.

Whole-cell patch-clamp recordings were made under both currentand voltage-clamp mode. Recording pipettes were made from borosilicate glass with a Flaming-Brown puller (Sutter Instruments; tip resistance $5-10 \mathrm{M} \Omega$ ). The pipette solution contained the following (in mM): $120 \mathrm{~K}$-gluconate, $10 \mathrm{NaCl}, 1 \mathrm{CaCl}_{2}, 10$ EGTA, $10 \mathrm{HEPES}, 5 \mathrm{Mg}$ ATP, $0.5 \mathrm{Na}-\mathrm{GTP}$, and 10 phosphocreatine. Perforated patch-clamp recordings were conducted in a subset of cells by including gramicidin (Sigma) in the pipette. Gramicidin was first dissolved in DMSO to a concentration of $2.5 \mathrm{mg} / \mathrm{ml}$ and then diluted in the pipette solution just before use to a final concentration of $2.5 \mu \mathrm{g} / \mathrm{ml}$ and sonicated for $10 \mathrm{~min}$. Before backfilling gramicidin-containing solution, the electrode tip was preloaded with gramicidin-free pipette solution. Reduction in the access resistance was monitored, and experiments begun when the resistance was stabilized at 50-90 Mohm and the resting membrane potential was $<-50 \mathrm{mV}$. Electrophysiological recordings were controlled by an EPC-9 amplifier combined with Pulse Software (HEKA Electronic) and analyzed using Igor Pro and mini-analysis (Synaptosoft). The signals were filtered at $2.9 \mathrm{kHz}$ and acquired at $10 \mathrm{kHz}$. Mouse recombinant R-spondin 3 (\#4120-RS-025/CF from R\&D Systems) was diluted in Ringer's solution at a concentration of $100 \mathrm{ng} / \mathrm{ml}(3.5 \mathrm{~nm})$.

In situ hybridization. DIG- or FITC-labeled riboprobes were synthesized using a DIG or FITC RNA labeling kit (11175025910, Roche). The template for lgr5, vesicular glutamate transporter 1 (vglut1), and R-spondin 3 gene was amplified from mouse OB cDNA by PCR and subcloned into vector pGEM-T Easy (A1360, Promega). Primers used to amplify cDNA were as follows: $\lg 5$ ( $5^{\prime}$-ACTCCCCTGTACATCTCTTCCA-3' and 5'-ATCTCATCCAGAAACGGGTATG-3'), vglut1 (5'-CAGAGCCGGAGGAGA TGA- $3^{\prime}$ and $5^{\prime}$-TTCCCTCAGAAACGCTGG-3'), and R-spondin 3 (5'TAATGACGACAGCTGGAGAAGA- $3^{\prime}$ and $5^{\prime}$-GTGGACCCATAGGCAGGTAATA-3').

Double FISH was performed as described previously (Fleming et al., 2012). Briefly, the sections were hybridized with $1-2 \mathrm{ng} / \mu \mathrm{l}$ of DIG, and FITC-labeled riboprobes diluted in hybridization buffer (containing 
$50 \%$ formamide, $5 \times$ SSC, $0.3 \mathrm{mg} / \mathrm{ml}$ yeast tRNA, $100 \mu \mathrm{g} / \mathrm{ml}$ heparin, $1 \times$ Denhardt's, 0.1\% Tween 20, 0.1\% CHAPS, 5 mm EDTA in RNase free $\mathrm{H}_{2} \mathrm{O}$ ) overnight under Parafilm at $62^{\circ} \mathrm{C}$. The sections were incubated in anti-FITC-POD (1:100 in 0.5\% blocking reagent; Roche, 11426346910) overnight at $4^{\circ} \mathrm{C}$. FITC riboprobes were developed using the TSA Plus system (PerkinElmer, NEL741001KT). Slides were then incubated overnight at $4^{\circ} \mathrm{C}$ with $\mathrm{AP}$-conjugated anti-DIG antibody (1:500 in PBT + $20 \%$ lamb serum). DIG-labeled riboprobes were developed using HNPP/ Fast Red TR system (Roche, 11758888001). Slides were then rinsed in PBS and mounted with Vectashield (Vector Laboratories).

Nissl staining. NeuroTrace 530/615 red fluorescent Nissl stain (ThermoFisher Scientific, N21482) was used to stain the Nissl substance in OB sections to identify neuronal cells. NeuroTrace stain was diluted 1:200 in PBS. The sections were covered with NeuroTrace stain, incubated for 20 $\mathrm{min}$ at room temperature, washed for $2 \mathrm{~h}$ at room temperature in PBS, and mounted in Vectashield.

Experimental design and statistical analysis. To count the cell numbers in different layers, a total of 16 counting squares in a single layer were randomly selected from each $\mathrm{OB}$ section. Unless otherwise specified, for each percentage including no coexpression (0\%), a total of 300-1000 cells from at least three sections of three different animals were counted and included in the calculation. The juxtaglomerular cells were defined as cells on the edge of each glomerulus. Counting was performed by someone who was blind to the experimental design to eliminate bias. Averaged data were derived from three different animals and expressed as mean \pm SEM. For naris closure experiments, paired Student's $t$ tests were performed between the open and closed side. For the effects of R-spondin 3 on Lgr5-EGFP ${ }^{+}$cells, paired Student's $t$ tests were performed between the preapplication and postapplication conditions. Electrophysiological parameters between Lgr5-EGFP ${ }^{+}$and Lgr5-EGFP ${ }^{-}$cells were compared using unpaired Student's $t$ tests. Statistical analysis was conducted using GraphPad Prism 6.0 software or Microsoft Excel built-in functions.

\section{Results}

\section{Lgr5 does not mark stem cells in the OB}

Adult neurogenesis occurs in several brain structures, including the OB (Ming and Song, 2011). Because Lgr5 labels stem cells in many other organs, we asked whether Lgr5 is expressed in the brain. In adult Lgr5-EGFP mice, the OB is the only brain structure that shows high level of Lgr5 expression. The Lgr5-EGFP expression pattern is consistent with a previous report (Miller et al., 2014) and with $\lg 5$ mRNA expression from the Allen Mouse Brain Atlas (Lein et al., 2007). Within the OB, Lgr5-EGFP ${ }^{+}$cells are found in the GL, MCL, and GCL (Fig. 1).

To elucidate whether Lgr5 labels stem cells in the OB, we stained OB sections from adult Lgr5-EGFP mice with Sox2 and Nestin, two stem cell markers in the nervous system, and found that Lgr5-EGFP ${ }^{+}$cells do not coexpress either marker (Fig. $1 A, B)$. Furthermore, Lgr5-EGFP ${ }^{+}$cells are not proliferating because they do not express Ki67 or incorporate BrdU (Fig. 1C,D). Similar results were also observed in embryonic (E18, Fig. 2A-C) and neonatal (P1, Fig. 2D-F) mice. Therefore, Lgr5 does not mark stem cells in the OB from early development to adulthood.

To further confirm that Lgr5-EGFP ${ }^{+}$cells in the OB do not function as stem cells, we performed genetic lineage tracing experiments by crossing Lgr5-EGFP-cre/ERT2 mice with Rosa26floxed STOP-tdTomato mice. Upon tamoxifen induction, Lgr5-EGFP ${ }^{+}$cells would be marked by both EGFP and tdTomato. If some Lgr5-EGFP ${ }^{+}$cells are stem cells, they will give rise to progeny cells, which likely turn down the expression of Lgr5 and thus are tdTomato ${ }^{+}$only. Up to $90 \mathrm{~d}$ after tamoxifen injection, we found that all tdTomato ${ }^{+}$cells also express EGFP (Fig. $3 A-D)$, arguing that the tdTomato ${ }^{+}$cells are not the progenies of Lgr5-EGFP ${ }^{+}$cells, but rather are themselves Lgr5-EGFP ${ }^{+}$cells.

\section{Lgr5-EGFP $^{+}$cells are terminally differentiated neurons in the $\mathrm{OB}$}

To reveal the identities of Lgr5-EGFP ${ }^{+}$cells in the OB, we stained the OB sections from adult Lgr5-EGFP mice with a variety of cell markers. Nearly all Lgr5-EGFP ${ }^{+}$cells in different layers of the OB were positively stained with NeuroTrace Nissl (Fig. 4A-D), suggesting that Lgr5-EGFP ${ }^{+}$cells are neurons. Consistent with this notion, Lgr5-EGFP ${ }^{+}$cells do not express GFAP, an astrocyte marker (Fig. 4E), and some are stained by NeuN, a nucleus marker for a subset of mature neurons in the OB (Fig. 4F, G; for Lgr5-EGFP ${ }^{+} / \mathrm{DCX}^{+}$immature neurons, see below).

Within the glomerular layer, nearly half of Lgr5-EGFP ${ }^{+}$cells express $\mathrm{TH}$, indicating that they are dopaminergic neurons (Fig. $4 H, L)$. These $\mathrm{TH}^{+}$cells are also GABAergic because virtually all $\mathrm{TH}^{+}$cells also express $\mathrm{GAD}^{+} 7^{+}$and a subset $(\sim 18 \%)$ expresses GAD65 (Parrish-Aungst et al., 2007; Kiyokage et al., 2010). We therefore quantified Lgr5-EGFP ${ }^{+}$cells based on their TH and GAD65 expression: $\operatorname{Lgr}^{+}{ }^{\mathrm{TH}}{ }^{+} \mathrm{GAD}^{+} 5^{+}(26 \%), \mathrm{Lgr}^{+} \mathrm{TH}^{+} \mathrm{GAD}^{-} 5^{-}$ (24\%), $\mathrm{Lgr}^{+} \mathrm{TH}^{-} \mathrm{GAD}^{+} 5^{+}(13 \%)$, and $\mathrm{Lgr}^{+}{ }^{\mathrm{TH}}{ }^{-} \mathrm{GAD}^{-} 5^{-}$ (37\%) (Fig. 4I-L). This indicated that these three molecules define distinct, but overlapping, subpopulations of neurons. Similar lineage tracing experiments confirmed that some $\mathrm{TH}^{+}$ and $\mathrm{GAD}_{65}{ }^{+}$cells are Lgr5-EGFP ${ }^{+}$, but they are unlikely the progeny of Lgr5-EGFP $^{+}$cells because all tdTomato ${ }^{+}$cells are also $\mathrm{EGFP}^{+}$(Fig. 5A,B,E,F). In contrast, Lgr5-EGFP ${ }^{+}$cells do not express the calcium binding protein CB or CR (Fig. $4 M, N$ ), which together account for nearly $38 \%$ of neurons in the glomerular layer (Parrish-Aungst et al., 2007). Consistently, none of the $\mathrm{CB}^{+}$or $\mathrm{CR}^{+}$cells are the progeny of Lgr5-EGFP ${ }^{+}$cells (Fig.

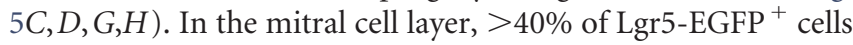
express a leucine-rich repeat membrane protein, 5T4 oncofetal trophoblast glycoprotein (Fig. 4O), which labels a subset of superficial GABAergic granule cells located in or near the mitral cell layer (Imamura et al., 2006; Yoshihara et al., 2012). A small population of Lgr5-EGFP ${ }^{+} / 5 \mathrm{~T}^{+}{ }^{+}$cells is also observed in the glomerular layer (Fig. 4P). Additionally, double in situ hybridization experiments reveal that some $\lg r 5^{+}$cells in the MCL and in the GL/EPL boundary express vglut1, supporting that these cells are glutamatergic mitral and tufted cells, respectively (Fig. 4Q-S). These data demonstrate that Lgr5 is expressed in multiple subtypes of neurons in different layers of the OB.

\section{Lgr5 is expressed in neurons at different maturation stages}

Because interneurons in the $\mathrm{OB}$ are continuously replenished from neuroblasts that migrate via the RMS from the SVZ (Lledo et al., 2008; Cave and Baker, 2009; Whitman and Greer, 2009), we asked whether Lgr5-EGFP $^{+}$cells are at different maturation stages. There are no Lgr5-EGFP ${ }^{+}$cells in the $\mathrm{OB}$ core region, RMS, or SVZ of Lgr5-EGFP mice (Fig. 1D3, OB core region). It is most likely that Lgr5 expression is initiated after the neuroblasts reach the $\mathrm{OB}$, although we cannot rule out the possibility that some Lgr5-EGFP ${ }^{+}$neurons are generated locally in the OB. As neurons become mature, they downregulate the expression of DCX (a microtubule-associated protein expressed in neuronal precursor cells and immature neurons) and upregulate the expression of NeuN (Brown et al., 2003). In addition to $\mathrm{NeuN}^{+}$ Lgr5-EGFP ${ }^{+}$cells (Fig. 4F,G), a subset of Lgr5-EGFP ${ }^{+}$cells (15\% in the glomerular layer and $10 \%$ in the mitral cell layer) coexpress DCX (Fig. 6A,B). Similarly, Lgr5-EGFP ${ }^{+} \mathrm{TH}^{+}$cells also contain both $\mathrm{DCX}^{+}(21 \%)$ and $\mathrm{NeuN}^{+}(30 \%)$ populations (Fig. 6C,D). These data indicate that Lgr5 is expressed in $\mathrm{OB}$ neurons at varying developmental stages. 

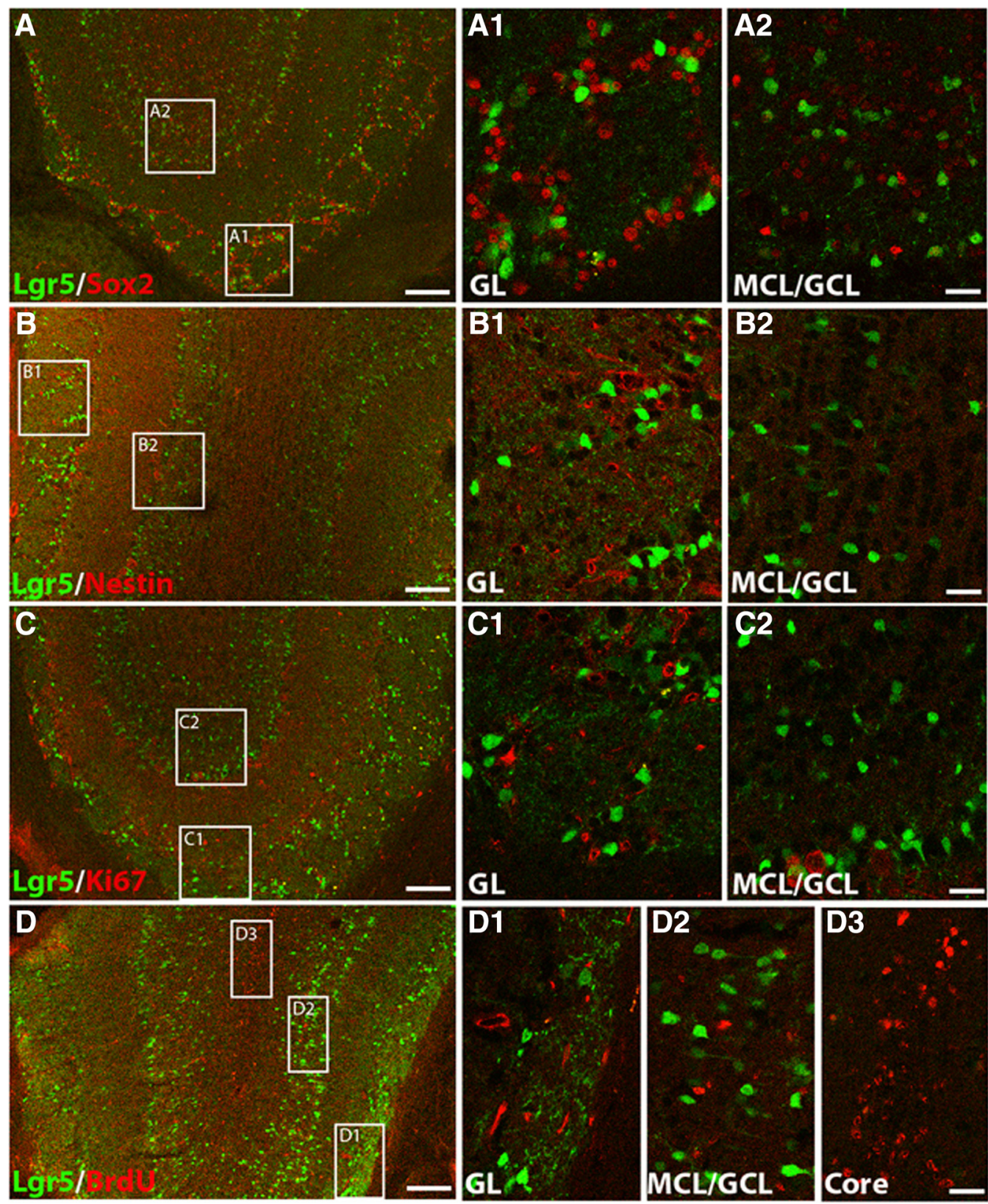

Figure 1. Lgr5 does not label stem cells in the OB. Coronal OB sections from adult Lgr5-EGFP mice were stained with stem cell marker Sox2 (A), Nestin (B), cell proliferation marker Ki67 (C), or BrdU (D). Many BrdU ${ }^{+}$cells are in the core region of the $0 B$, where there is no EGFP signal (D3). Scale bars: $A-D, 100 \mu \mathrm{m} ; \mathbf{A 2}, \mathbf{B 2}, \mathbf{C}, \mathbf{D} 3,20 \mu \mathrm{m}$.

\section{Unlike TH and 5T4, Lgr5 does not show activity-dependent} expression

Because both TH and 5T4 show activity-dependent expression in the OB (Baker et al., 1993; Yoshihara et al., 2012) and overlap with Lgr5 (Fig. 4), we asked whether Lgr5 expression is also activity-dependent. Unilateral naris closure was performed on neonatal mice, and Lgr5-EGFP expression was compared between the open and closed sides $30 \mathrm{~d}$ later. No significant difference was observed in the number of Lgr5$\mathrm{EGFP}^{+}$cells in different layers of the $\mathrm{OB}$ (Fig. 7A). In contrast, in the glomerular layer, the percentage of $\mathrm{TH}^{+}$cells among Lgr5-EGFP ${ }^{+}$cells was decreased by $36 \%(p=0.01)$ in the closed side due to reduced TH expression (Fig. 7B1-B3). Similarly, in the mitral cell layer, the percentage of $5 \mathrm{~T}^{+}{ }^{+}$cells among Lgr5-EGFP ${ }^{+}$cells was decreased by $42 \%(p=0.01)$ in the closed side (Fig. 7C1-C3).
We next examined whether sensory deprivation affects maturation of Lgr5-EGFP $^{+}$cells. The percentage of $\mathrm{DCX}^{+}$cells among Lgr5-EGFP ${ }^{+}$cells in the GL was increased by $48 \%$ in the closed side (Fig. $7 D 1, D 2, D 5 ; p=0.03$ ), and increased by $126 \%$ in the GCL (Fig. 7D3-D5; $p=0.03$ ), indicating that sensory deprivation leads to accumulation of immature Lgr5-EGFP $^{+}$neurons. Together, Lgr5 does not show activity-dependent expression in the $\mathrm{OB}$, even though sensory input plays a role in maturation of these neurons.

Lgr5-EGFP ${ }^{+}$cells show heterogeneity in electrophysiological properties

We further investigated the functional properties of Lgr5-EGFP ${ }^{+}$ neurons in the OB by patch-clamp recoding in the glomerular layer, where we observed the strongest Lgr5-EGFP expression (Fig. 8A). Under current-clamp mode, depolarizing current in- 

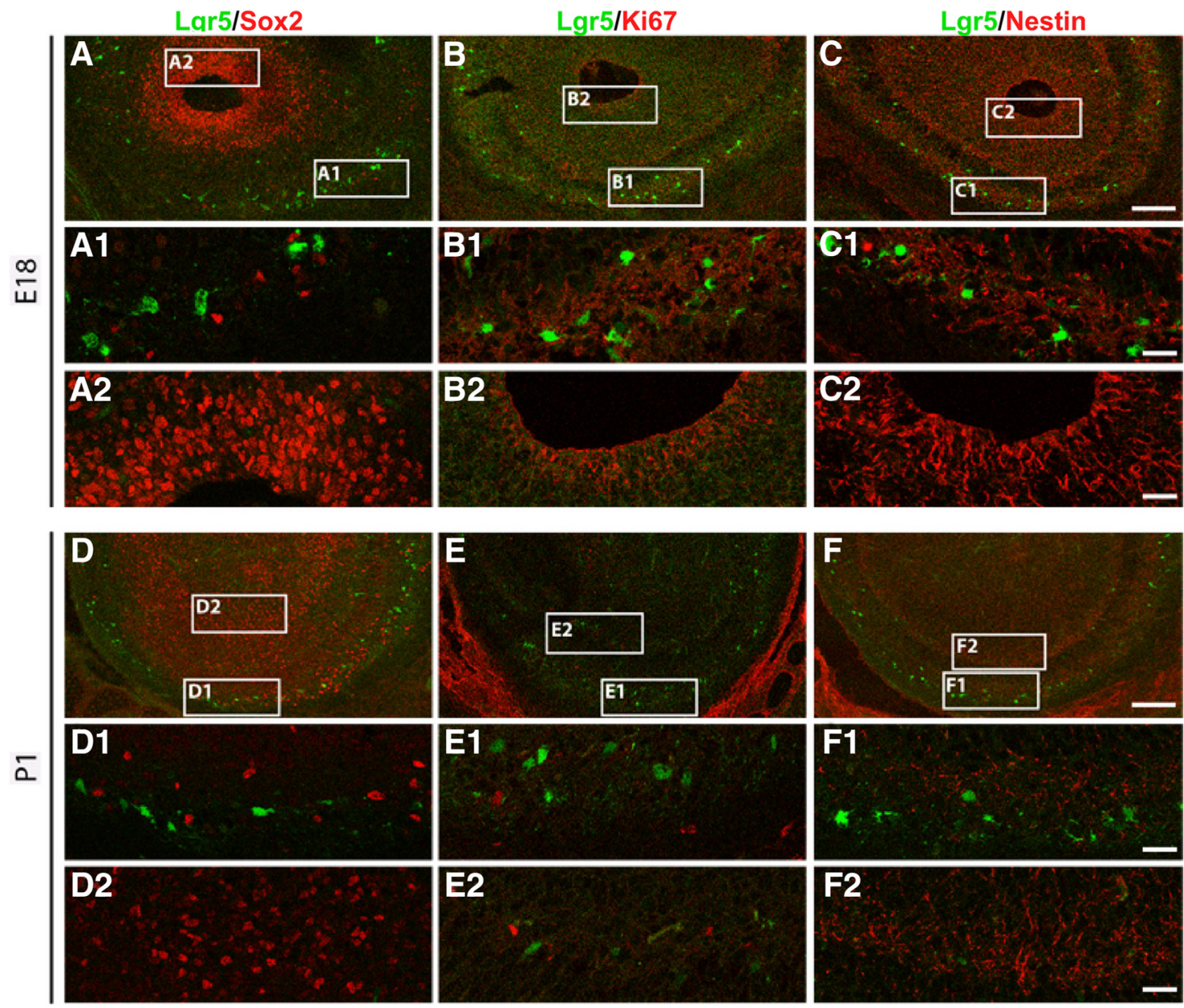

Figure 2. Lgr5 does not mark stem cells in the OB at prenatal and neonatal stages. $A-C$, At embryonic day 18 (E18), Lgr5-EGFP ${ }^{+}$cells do not coexpress Sox2 (A, $\left.\boldsymbol{A} 1\right)$, Ki67 (B, B1), or Nestin (C, C1) in the GL. In the core region where Lgr5-EGFP expression is absent, there are abundant Sox2 ${ }^{+}(\mathbf{A 2}), \mathrm{Ki}^{+} 7^{+}(\boldsymbol{B 2})$, and Nestin ${ }^{+}(\mathbf{C} 2)$ cells. $\boldsymbol{D}-\boldsymbol{F}$, At postnatal day 1 (P1), Lgr5-EGFP ${ }^{+}$cells do not express Sox2 (D), Ki67 (E), or Nestin (F) in the GL (D1-F1) or MCL/GCL (D2-F2). Scale bars: $\boldsymbol{C}, \boldsymbol{F}, 100 \mu \mathrm{m} ; \mathbf{C 1}, \mathbf{C}, \boldsymbol{F 1}, \boldsymbol{F 2}, 20 \mu \mathrm{m}$. Each scale bar applies to the entire row.
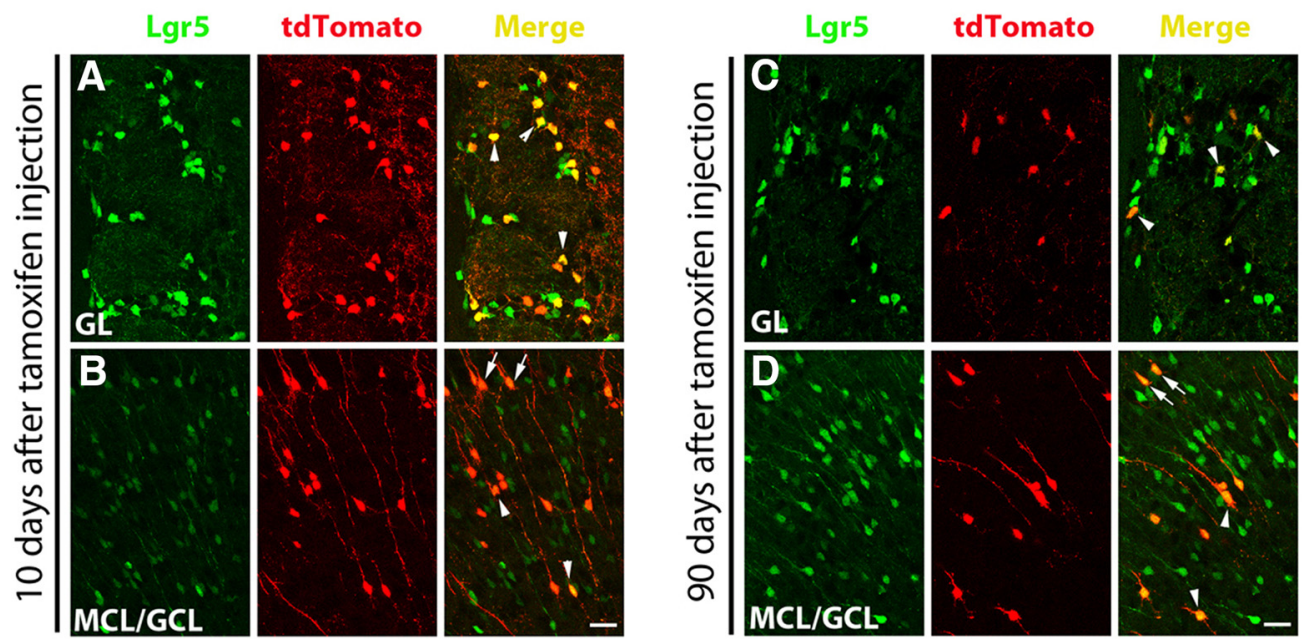

Figure 3. Lgr5-EGFP ${ }^{+}$cells do not give rise to other cells in the OB. Genetic lineage tracing was performed in Lgr5-EGFP-cre/ERT2 and Rosa26-floxed STOP-tdTomato mice at $10 \mathrm{~d}(\boldsymbol{A}, \boldsymbol{B})$ and $90 \mathrm{~d}$ $(\boldsymbol{C}, \boldsymbol{D})$ after tamoxifen induction. All tdTomato ${ }^{+}$cells are also $\mathrm{Lgr5}_{\text {-EGFP }}{ }^{+}$in the $\mathrm{GL}(\boldsymbol{A}, \boldsymbol{C}$, arrowheads), MCL $(\boldsymbol{B}, \boldsymbol{D}$, arrows), and GCL (B, $\boldsymbol{D}$, arrowheads). Scale bars, $20 \mu \mathrm{m}$. Each scale bar applies to the entire panel.

jections elicited action potentials in all Lgr5-EGFP ${ }^{+}$cells (Fig. $8 B$ ). The firing patterns of both Lgr5-EGFP ${ }^{+}$and Lgr5-EGFP ${ }^{-}$ cells in the glomerular layer could be categorized as tonic firing, delayed firing, bursting, or single-spike, similar to random re- cordings from juxtaglomerular neuron populations (McQuiston and Katz, 2001). These results confirm that Lgr5-EGFP ${ }^{+}$cells in the glomerular layer are postmitotic, functional neurons, comprising a heterogeneous population. 

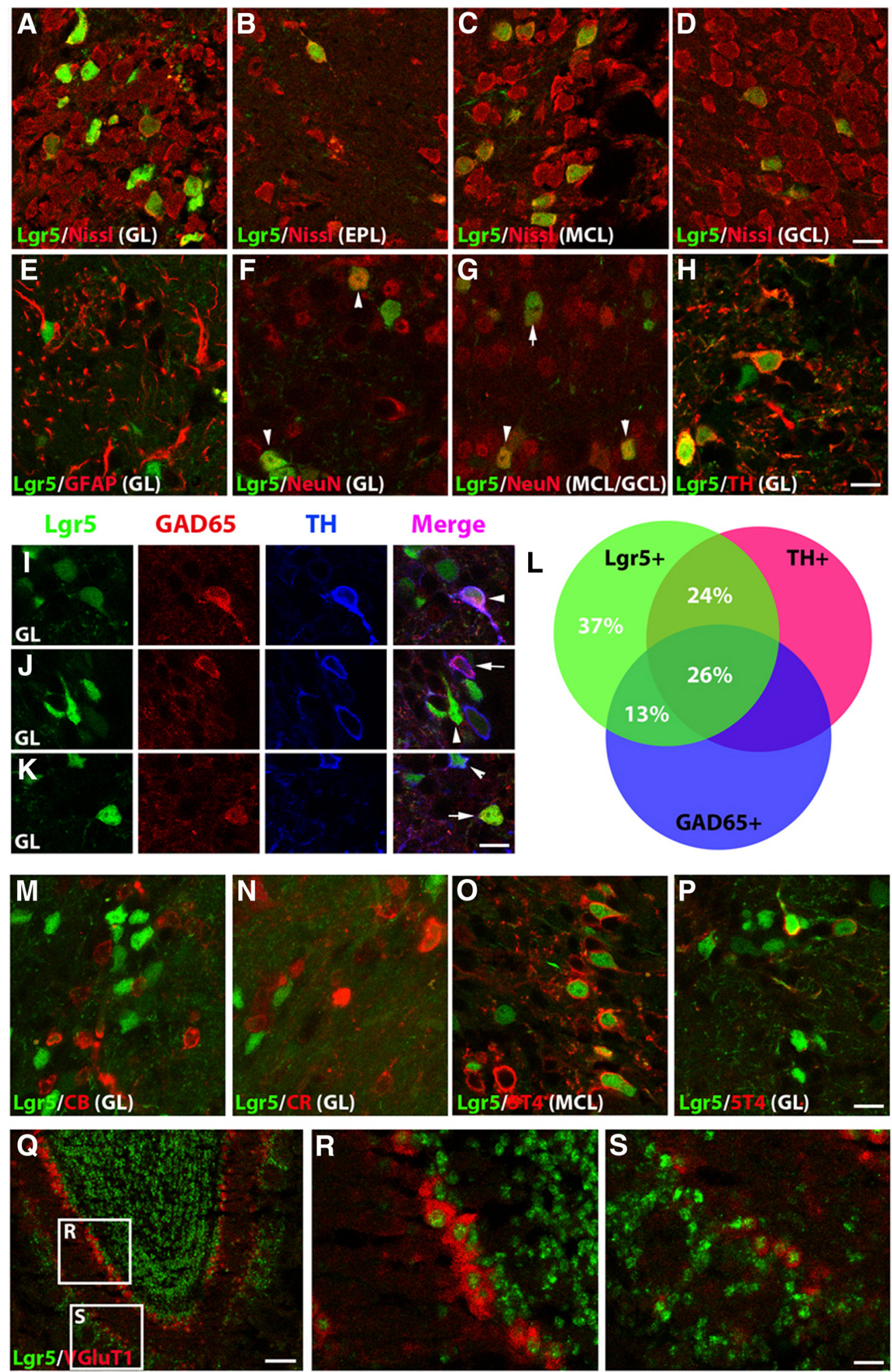

Figure 4. Lgr5 marks several subtypes of neurons in the OB. $A-D$, Coronal $0 B$ sections from adult Lgr5-EGFP mice were stained with Nissl. Nearly all Lgr5-EGFP ${ }^{+}$cells are Nissl ${ }^{+}$in the GL $(\boldsymbol{A}, 89 \%), \mathrm{EPL}(\boldsymbol{B}, 100 \%), \mathrm{MCL}(\boldsymbol{C}, 94 \%)$, and GCL (D, 84\%). $\boldsymbol{E}-\boldsymbol{H}, \mathrm{Lgr5}-\mathrm{EGFP}{ }^{+}$cells are not positively stained by astrocyte marker GFAP (E), but a subset is positively stained by neuronal cell marker NeuN in the GL (28\%) $(\boldsymbol{F})$ and MCL/GCL (41\%) (G), and by dopaminergic neuron marker TH $(\boldsymbol{H}) . \boldsymbol{I}-\mathbf{L}, \mathrm{Lgr5}$, GAD65, and TH show distinct but overlapping expression in the glomerular layer. Examples

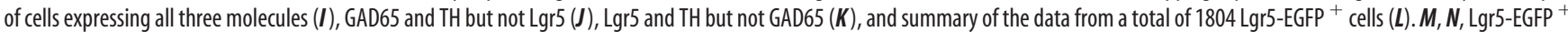
cells do not coexpress $\mathrm{CB}(\boldsymbol{M})$ or $\mathrm{CR}(\boldsymbol{N})$. $\mathbf{0}$, Approximately $41 \%$ of Lgr5-EGFP ${ }^{+}$cells in the MCL express $5 T 4$. $\boldsymbol{P}, \mathrm{A}$ small population of $\mathrm{Lgr5}{ }^{+} / 5 \mathrm{~T} 4^{+}$cells is present in the GL. Q-S, Double in situ hybridization using lgr5 and vlgut 7 riboprobes showed coexpression of these two genes in a subset of cells (Q) located at MCL $(\boldsymbol{R})$ and GL/EPL border (S). Scale bars: $\mathbf{D}, \boldsymbol{H}, \boldsymbol{P}, 10 \mu \mathrm{m}$ (each applies to the entire row); $\boldsymbol{K}, 10 \mu \mathrm{m}$ (applies to the entire panel); $\mathbf{Q}, 100 \mu \mathrm{m} ; \boldsymbol{S}, 20 \mu \mathrm{m}$ (also applies to $\boldsymbol{R}$ ). 


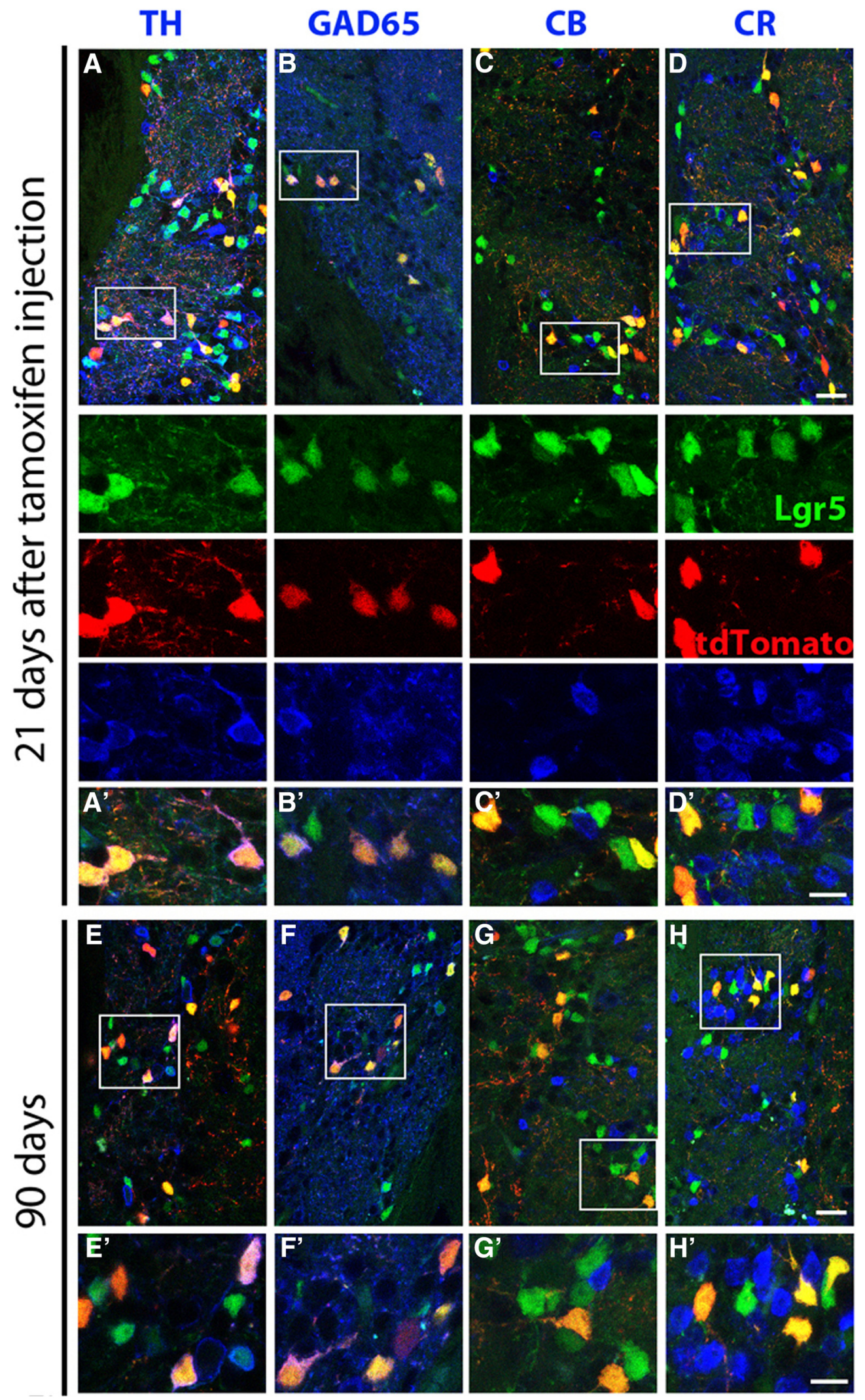

Figure 5. Lgr5-EGFP ${ }^{+}$cells do not give rise to other neuronal cell types in the OB. Genetic lineage tracing was performed in Lgr5-EGFP-cre/ERT2 and Rosa26-floxed STOP-tdTomato mice at $21 \mathrm{~d}$ $(\boldsymbol{A}-\boldsymbol{D})$ and $90 \mathrm{~d}(\boldsymbol{E}-\boldsymbol{H})$ after tamoxifen induction. All tdTomato ${ }^{+}$cells are also EGFP ${ }^{+}$, suggesting that they are Lgr5-EGFP ${ }^{+}$cells rather than the progenies from Lgr5-EGFP ${ }^{+}$cells. Some

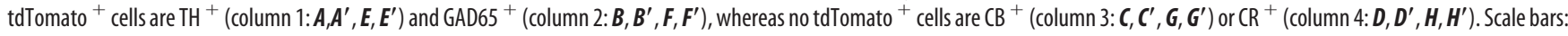
$\boldsymbol{D}, \boldsymbol{H}, 20 \mu \mathrm{m} ; \boldsymbol{D}^{\prime}, \boldsymbol{H}^{\prime}, 10 \mu \mathrm{m}$. Each scale bar applies to the entire row. 

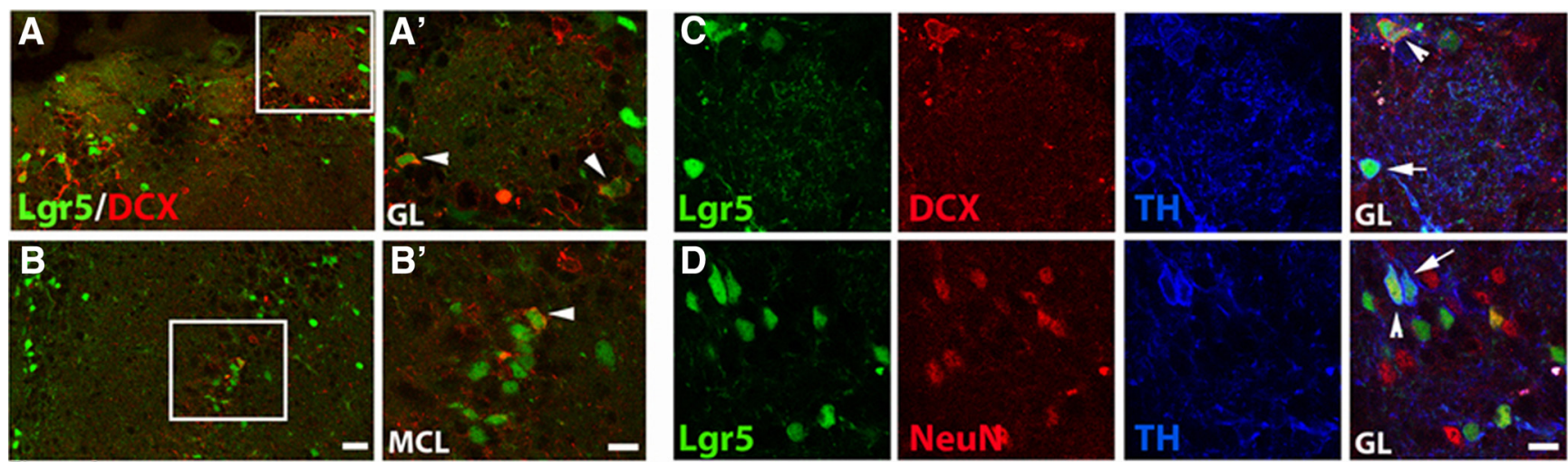

Figure 6. Lgr5-EGFP ${ }^{+}$cells in the $\mathrm{OB}$ are at different stages of maturation. $\boldsymbol{A}, \boldsymbol{B}$, A subset of Lgr5-EGFP ${ }^{+}$cells (green) coexpresses DCX (red) in both the GL (15\%) (A) and MCL (10\%) $(\boldsymbol{B})$. $\boldsymbol{A}^{\prime}, \boldsymbol{B}^{\prime}$ Enlarged images within the rectangles. $\boldsymbol{C}, \boldsymbol{D}$, In the GL, a subset of Lgr5-EGFP ${ }^{+} / \mathrm{TH}^{+}$cells coexpresses DCX (arrowhead; $21 \%$ ) (C) or NeuN (arrowhead; $30 \%$ ) (D). Arrows indicate $L$ gr5-EGFP ${ }^{+} / \mathrm{TH}^{+}$ cells that do not express $D C X(C)$ or NeuN (D). Scale bars: $\boldsymbol{B}, 20 \mu \mathrm{m} ; \boldsymbol{B}^{\prime}, \boldsymbol{D}, 10 \mu \mathrm{m}$.

Juxtaglomerular neurons participate in interglomerular and intraglomerular circuits, making synaptic contacts with sensory neuron axon terminals, mitral/tufted cell dendrites, and other juxtaglomerular cells. Spontaneous EPSCs (sEPSCs) in Lgr5$\mathrm{EGFP}^{+}$cells demonstrated that these cells are integrated into the OB neural circuits (Fig. 8C). Curiously, sEPSCs recorded in Lgr5$\mathrm{EGFP}^{+}$cells exhibited similar event frequencies but significantly larger amplitudes compared with Lgr5-EGFP ${ }^{-}$cells (Fig. 8D).

An Lgr 5 ligand R-spondin 3 is expressed in the olfactory bulb In other cell types and tissues, Lgr5 has been shown to bind $\mathrm{R}$-spondins and regulate the Wnt signaling pathway (Carmon et al., 2011; Glinka et al., 2011; de Lau et al., 2011). R-spondin family contains four secreted proteins (1-4), all of which are potential ligands for Lgr5 (Carmon et al., 2011). We set out to investigate the expression patterns of R-spondin 1-4 in the mouse OB by searching the in situ hybridization data from Allen Mouse Brain Atlas (Lein et al., 2007) and Allen Developing Mouse Brain Atlas (Sunkin et al., 2013). We found that only R-spondin 3 is expressed in the adult $\mathrm{OB}$ (Fig. 9A), which was further confirmed by double in situ hybridization of Lgr5 and R-spondin 3 (Fig. 9B). This finding suggests that Lgr 5 can be activated by an endogenous ligand in the OB.

Given that Lgr5-EGFP ${ }^{+}$cells showed larger sEPSCs than Lgr5-EGFP ${ }^{-}$cells (Fig. 8D), we reasoned that binding of R-spondin 3 to Lgr5 could have either an acute effect on synaptic function or chronic effect on synaptic formation or maintenance via Wnt signaling (Dickins and Salinas, 2013; Purro et al., 2014). We directly assessed the first possibility by examining the effect of perfusion of R-spondin 3 on the electrophysiological properties of Lgr5-EGFP $^{+}$cells using both whole-cell and perforated patch clamp. The latter recording configuration maintains the integrity of second messenger signaling cascades while gaining electrical access to the cells via antibiotic pores. Perfusion of R-spondin 3 at $100 \mathrm{ng} / \mathrm{ml}$ (or $3.5 \mathrm{~nm}$ ) for $10 \mathrm{~min}$ did not cause significant changes in resting membrane potentials or sEPSCs (Fig. 9C). The concentration of R-spondin 3 we used was presumably a saturating dose for binding Lgr 5 because the median effective dose is $<1$ $\mathrm{ng} / \mathrm{ml}$ according to the manufacturer's datasheet and the halfmaximum effective concentration is $0.01 \mathrm{nM}$ in cultured cells (Carmon et al., 2011). These results suggest that Lgr5 and its ligand may exert their functions in the $\mathrm{OB}$ in a chronic manner as discussed below.

\section{Discussion}

In this study, we investigated the identities and properties of Lgr5-EGFP ${ }^{+}$cells in the $\mathrm{OB}$ using an Lgr5 reporter mouse line as well as genetic lineage tracing. Immunostaining with various molecular markers reveals that Lgr5-EGFP ${ }^{+}$cells in the OB are not stem cells but rather are fully differentiated neurons of various subtypes and maturation stages. Patch-clamp recordings reveal that these neurons fire action potentials and display spontaneous postsynaptic events. Genetic lineage tracing reveals that Lgr5$\mathrm{EGFP}^{+}$cells do not give rise to other OB cells in adult animals. These data indicate that Lgr5-EGFP ${ }^{+}$cells in the OB represent a nonstem cell lineage, implying distinct roles of Lgr5 in postmitotic neurons.

In the past 10 years, Lgr5 has been established as a marker for epithelial stem cells in many body organs, including sensory organs (for references, see Introduction). The OB is a brain region that undergoes continuous neurogenesis and expresses Lgr5 at high levels. Surprisingly, Lgr5-EGFP ${ }^{+}$cells in the adult or developing OB do not coexpress neuronal stem cell markers Sox 2 and Nestin, do not proliferate, nor do they give rise to other cells (Figs. 1, 2-3, 5), indicating that Lgr5-EGFP ${ }^{+}$cells are not progenitor/stem cells in the OB. Instead, Lgr5-EGFP ${ }^{+}$cells are postmitotic neuronal cells in different $O B$ layers and at different maturation stages because they are stained for Nissl body and other neuronal markers (Figs. 2, 3).

In the glomerular layer, the juxtaglomerular cells are subdivided into three major types: the ET cells, SA cells, and PG cells. Each type can be further divided into several subtypes based on their anatomical and/or neurochemical properties. Lgr5 is expressed in a heterogeneous population of neurons in the glomerular layer but with preference in certain subtypes. For instance, nearly $50 \%$ of $\mathrm{Lgr} 5-\mathrm{EGFP}^{+}$cells are $\mathrm{TH}^{+}$, dopaminergic cells (Fig. 4), which account for only $10 \%$ of juxtaglomerular cells (Parrish-Aungst et al., 2007). The $\mathrm{TH}^{+}$cells can be further divided into two major subpopulations, including GAD65 ${ }^{+}$uniglomerular PG cells and GAD67 ${ }^{+}$multiglomerular short axon cells, which innervate one and multiple (from a handful to tens of) glomeruli, respectively (Kiyokage et al., 2010). Among Lgr5$\mathrm{EGFP}^{+}$cells, $26 \%$ of them express both TH and GAD65 and most likely belong to uniglomerular PG cells. Another $24 \%$ express TH but not GAD65 and most likely belong to short axon cells (Fig. 4), which modulate information transmission in the $\mathrm{OB}$ via interglomerular interactions (Kiyokage et al., 2010; Whitesell et al., 2013; 

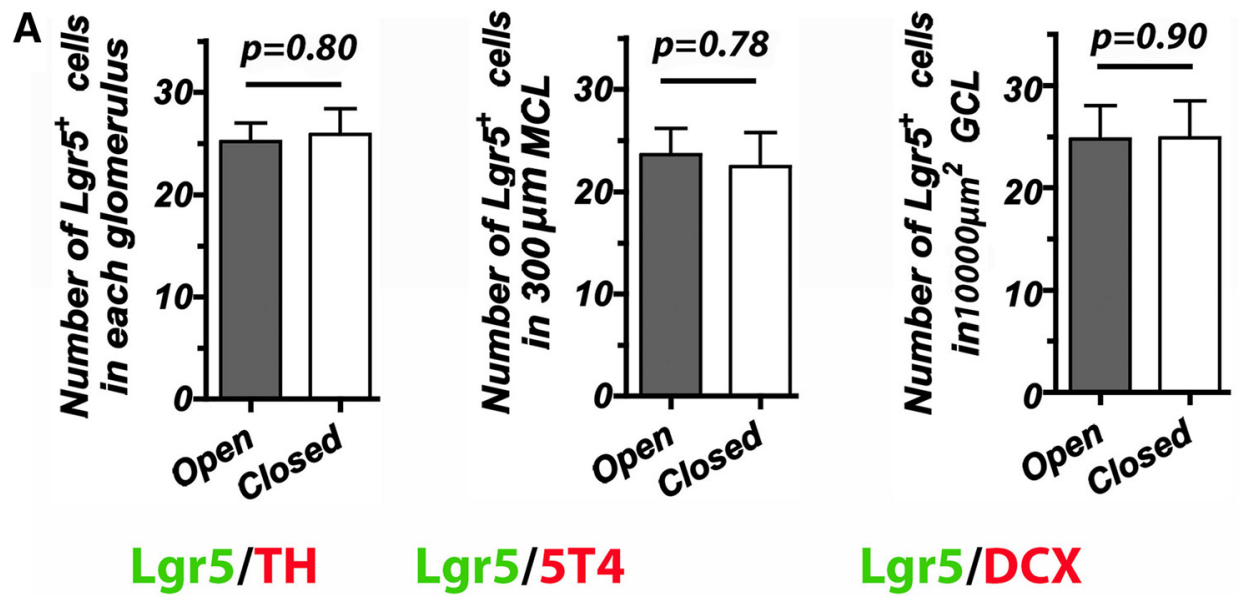

Lgr5/DCX
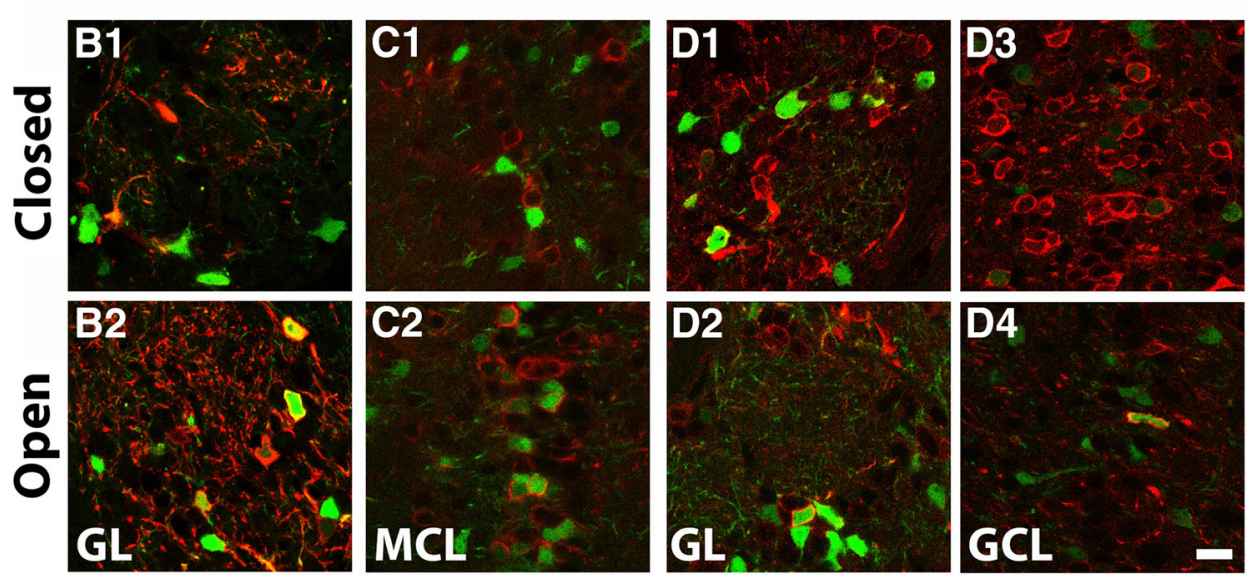

B3

\section{C3}

D5
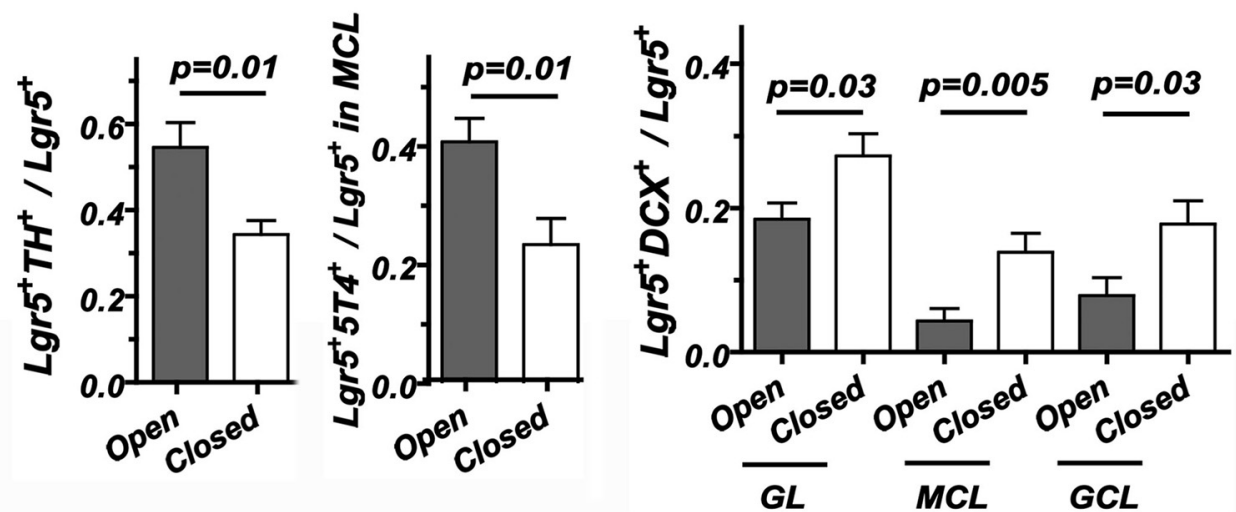

Figure 7. Lgr5 expression is independent of sensory inputs. $A$, Sensory deprivation did not alter the number of Lgr5-EGFP ${ }^{+}$cells in the GL ( $25 \pm 2 / g$ lomerulus in the open side, $n=24$ sections; $26 \pm 3$ in the closed side, $n=24$ sections), MCL ( $24 \pm 3$ cells $/ 300 \mu \mathrm{m}$ linear length in the open side, $n=24$ sections; $22 \pm 3$ in the closed side, $n=24$ sections), or GCL ( $25 \pm 3$ cells $/ 100 \times 100 \mu \mathrm{m}^{2}$ in the open side, $n=24$ sections; $25 \pm 4$ in the closed side, $n=24$ sections). $\boldsymbol{B} 1-\boldsymbol{B} 3$, The percentage of Lgr5-EGFP ${ }^{+} \mathrm{TH}^{+} / \mathrm{Lgr5}$-EGFP ${ }^{+}$cells in the GL decreased in the closed side (B1:35 $\pm 4 \%, n=21$ sections) compared with the open side (B2: $55 \pm 6 \%, n=21$ sections), summarized in B3. C1-C3, The percentage of Lgr5-EGFP ${ }^{+} 5 \mathrm{~T} 4^{+} / \mathrm{Lgr5}^{-E G F P}{ }^{+}$cells in the closed MCL (C1:23 $\pm 5 \%, n=21$ sections) decreased compared with the open MCL (C2:39 $\pm 6 \%, n=21$ sections), summarized in C3. D1-D5, Expression of DCX was increased in the closed GL (D1:33 $\pm 4 \%, n=24$ sections) and GCL (D3: $19 \pm 4 \%, n=24$ sections) compared with the open side (D2: $22 \pm 3 \%$ in GL; D4: $11 \pm 3 \%$ in GCL, $n=24$ sections), summarized in D5. Scale bar, $10 \mu \mathrm{m}$. $p$ values: paired $t$ test.

Banerjee et al., 2015; Liu et al., 2016). In contrast, Lgr5 is not expressed in calcium binding protein $\mathrm{CB}^{+}$or $\mathrm{CR}^{+}$cells (Fig. 4), which together account for $37 \%$ of juxtaglomerular cells (ParrishAungst et al., 2007) and define a subset of anaxonic (without typical axons) PG cells (Kosaka et al., 2008; Kosaka and Kosaka, 2011). Overall, Lgr5 expression is not random among GABAergic neurons in the glomerular layer but shows strong preference in dopaminergic $\mathrm{TH}^{+}$cells over $\mathrm{CB}^{+}$and $\mathrm{CR}^{+}$cells. It is worth noting that the immunohistochemistry data may underestimate the percentage of $\mathrm{TH}^{+}$or $\mathrm{GAD}^{+}$cells among $\mathrm{Lgr} 5^{+}$cells due to possible inefficiency of the antibodies. In addition, Lgr5 is also expressed in a subset of excitatory, external tufted cells located in the GL/EPL boundary, revealed by double in situ hybridization of $\operatorname{lgr} 5$ and vglut1 mRNAs due to weak staining of the cell bodies by the VGluT1 antibody (Fig. 4).

Similarly, in the mitral cell layer, Lgr5 is also expressed in a heterogeneous population of cells, including both excitatory and inhibitory neurons with preference in certain cell types. Nearly 
A

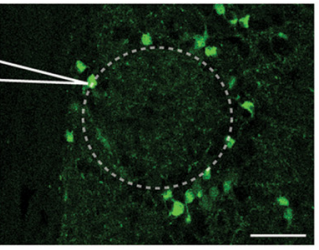

C

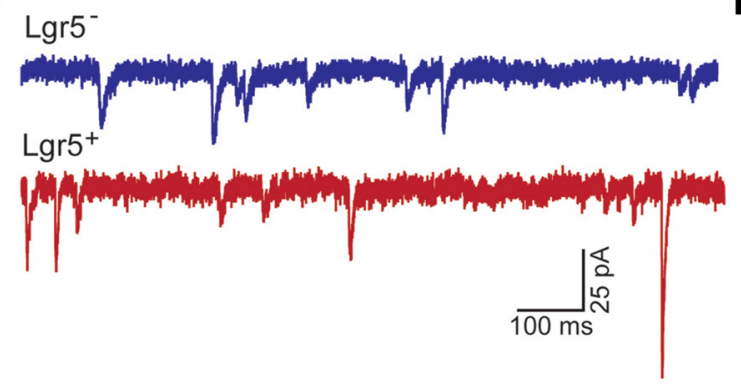

B

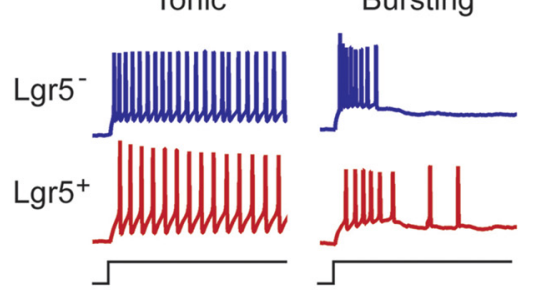

D

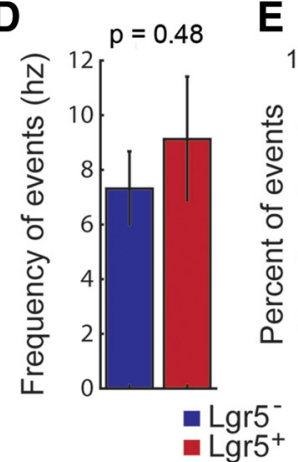

Delayed-firing Single-spike

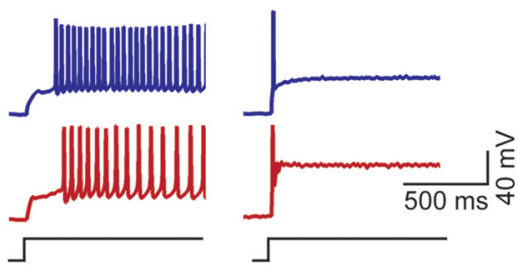

$\mathbf{E}$

Figure 8. Whole-cell patch-clamp recordings reveal the electrophysiological properties of Lgr5-EGFP ${ }^{+}$cells in the GL. A, Fluorescent cells in the GL were observed in the $0 B$ slices from adult Lgr5-EGFP mice and targeted for whole-cell patch-clamp recordings. Scale bar, $50 \mu \mathrm{m}$. B, Representative current-clamp recordings from Lgr5-EGFP ${ }^{-}$and Lgr5-EGFP ${ }^{+}$cells in the GL. These diverse firing patterns were representative of juxtaglomerular neurons. $\mathbf{C}-\boldsymbol{E}$, Voltage-clamp recordings $\left(\mathrm{V}_{\text {hold }}=-70 \mathrm{mV}\right)$ demonstrated that both $\mathrm{Lgr5} \mathrm{EGFP}^{-}$and $\mathrm{Lgr5}^{-\mathrm{EGFP}}{ }^{+}$cells received synaptic inputs in the form of sEPSCS. Whereas the frequency (D) of sEPSCs was not different between the two groups (Lgr5-EGFP ${ }^{-}, 7.3 \pm 1.4 \mathrm{~Hz}$ vs Lgr5-EGFP $\left.{ }^{+}, 9.1 \pm 2.3 \mathrm{~Hz}\right)$, the amplitude $(\boldsymbol{E})$ was significantly higher in Lgr5-EGFP ${ }^{+}(164.6 \pm 30.5 \mathrm{pA}, n=13)$ than Lgr5-EGFP ${ }^{-}$cells $(93.0 \pm 8.6 \mathrm{pA}, n=17)$. p values: unpaired $t$ test.
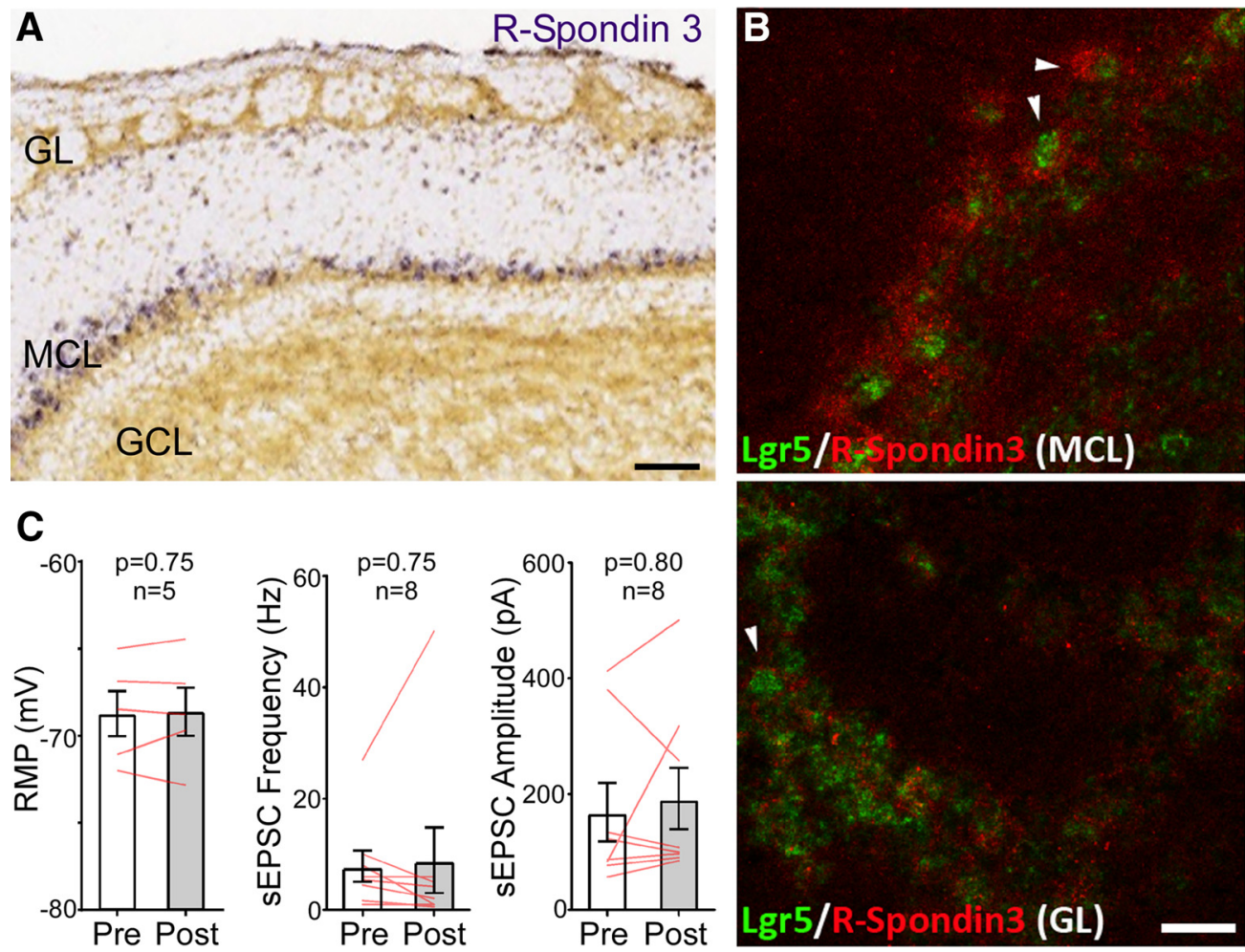

Figure 9. R-spondin 3, a ligand for Lgr5, is expressed in the olfactory bulb. A, In situ hybridization of $R$-spondin 3 in the olfactory bulb. Image was taken from Allen Developing Mouse Brain Atlas (http://developingmouse.brain-map.org/experiment/show/100042471). Scale bar, $100 \mu \mathrm{m}$. B, Double in situ hybridization using /gr5 (green) and R-spondin 3 (red) riboprobes showed expression of these two genes in the $\mathrm{OB}$. Arrowheads indicate costained cells. $A, B$, Results were from 1-month-old mice, but similar results were observed from 2-month-old mice. Scale bar, $20 \mu \mathrm{m}$. $C$, Bath perfusion of R-spondin 3 did not change the resting membrane potential (RMP), SEPSC frequency, and sEPSC amplitude. Each red line connects the values of preapplication and postapplication of R-spondin 3 from a single cell. The data for the RMP were obtained from perforated patch clamp, whereas those for sEPSCs were from whole-cell patch clamp. An additional two cells in perforated patch-clamp configuration also showed no alteration in sEPSC frequency and amplitude after R-spondin 3 perfusion. The recordings typically lasted 15 min after perfusion onset of R-spondin 3. $p$ values: paired $t$ test. 
$40 \%$ of Lgr5-EGFP ${ }^{+}$cells are $5 \mathrm{~T}^{+}$, which labels a subset of superficial granule cells and plays a role in the formation or maintenance of dendritic ramification or synaptic connection (Imamura et al., 2006; Yoshihara et al., 2012). Considering that 5T4 ${ }^{+}$ only account for $14 \%$ of $\mathrm{NeuN}^{+}$cells while nearly all $5 \mathrm{~T}^{+}{ }^{+}$cells are $\mathrm{NeuN}^{+}$(Imamura et al., 2006), Lgr5 expression shows strong preference in $5 \mathrm{~T}^{+}{ }^{+}$cells. Interestingly, Lgr5 expression does not show any activity dependence, even though both $\mathrm{TH}$ and 5T4 expression is significantly reduced after naris closure (Baker et al., 1993; Yoshihara et al., 2012). Consequently, the percentage of Lgr5-EGFP ${ }^{+} \mathrm{TH}^{+}$and Lgr5-EGFP ${ }^{+} 5 \mathrm{~T}^{+}{ }^{+}$cells shows a significant reduction upon sensory deprivation (Fig. 7).

Lgr5 is not only expressed in heterogeneous cell types, but also at different maturation stages in the OB (Fig. 6). NeuN, a pan neuronal nuclear marker in vertebrates, is expressed in neurons undergoing withdrawal from the cell cycle and/or with the initiation of terminal differentiation (Mullen et al., 1992). Thus, $\mathrm{NeuN}$ is widely used as a marker for mature neurons, especially for those with downregulated expression of markers in the early stages of neuronal development, such as DCX (Brown et al., 2003; Couillard-Despres et al., 2005). However, only a relatively small portion of OB cells are $\mathrm{NeuN}^{+}(25 \%$ in the GL and $29 \%$ in the MCL) (Parrish-Aungst et al., 2007). Thus, NeuN staining may underestimate mature neurons in the OB. Nonetheless, among $\mathrm{Lgr}^{+}$cells, $28 \%$ in the GL and $41 \%$ in the MCL/GCL are $\mathrm{NeuN}^{+}$ (Fig. 6), consistent with previous reports in the OB (ParrishAungst et al., 2007). This probably explains why the summed percentage of mature $\left(\mathrm{NeuN}^{+}\right)$and immature $\left(\mathrm{DCX}^{+}\right)$Lgr5EGFP $^{+}$cells is much lower than 100\% (43\% in the GL and 51\% in the MCL/GCL).

DCX is expressed in neuronal precursors (neuroblasts) and newly generated neurons (Brown et al., 2003; Couillard-Despres et al., 2005). DCX ${ }^{+}$cells are enriched throughout the RMS (Nacher et al., 2001) and generate different subtypes of local interneurons (Lledo et al., 2008; Cave and Baker, 2009; Whitman and Greer, 2009). There are no Lgr5-EGFP ${ }^{+}$cells in the RMS, suggesting that Lgr5 expression is initiated after the progenitor cells reach the OB. Lgr5-EGFP ${ }^{+} / \mathrm{DCX}^{+}$cells are found in different layers of the $\mathrm{OB}$ and most likely mature into the specific subtypes of $\mathrm{Lgr}^{+}{ }^{+}$neurons in the OB. Unilateral naris closure causes an increase in the percentage of $\mathrm{Lgr}^{+} / \mathrm{DCX}^{+}$cells in all OB layers, suggesting that maturation of $\mathrm{Lgr}^{+}{ }^{+}$neurons depends on sensory inputs.

Consistent with the heterogeneity of Lgr5-EGFP ${ }^{+}$cells in the $\mathrm{OB}$, patch-clamp recordings demonstrate comparable firing patterns between Lgr5-EGFP ${ }^{+}$and Lgr5-EGFP ${ }^{-}$cells in the glomerular layer (Fig. 8). Interestingly, Lgr5-EGFP ${ }^{+}$cells exhibit sEPSCs with significantly larger amplitudes compared with Lgr5EGFP $^{-}$cells. This may be due to biased expression of Lgr5 in certain subtypes of neurons ( such as $\mathrm{TH}^{+}$) if these subtypes exhibit larger sEPSCs. Alternatively, the larger EPSCs observed in Lgr5-EGFP ${ }^{+}$cells may reflect the potential role of Lgr5 and its ligand R-spondin 3 in regulating synaptic connections in the OB. The Wnt signaling pathway plays critical roles in synaptic formation and maintenance in the nervous system, and disruption of this pathway leads to synaptic disassembly in neurodegenerative diseases (Dickins and Salinas, 2013; Purro et al., 2014). Because new neurons are constantly generated and incorporated into the OB circuit (Ming and Song, 2011; Lepousez et al., 2015) and the $\mathrm{OB}$ is the only brain structure that expresses Lgr5 at high level in adulthood, it is tempting to speculate that Lgr5 and its ligand R-spondin 3, which is also expressed in the $\mathrm{OB}$ (Fig. 9), regulates synaptic formation and maintenance in the adult $\mathrm{OB}$ via the Wnt signaling pathway. Because of embryonic lethality of Lgr5 knockout mice, generating OB-specific Lgr5 knock-out or knockdown models is needed in future studies to reveal distinct roles of Lgr5 in the $\mathrm{OB}$ neural circuit.

In conclusion, our study reveals that Lgr5, a progenitor/stem cell marker in many tissues, defines a heterogeneous population of neuronal cells in the OB circuit, suggesting a potential novel function for Lgr5 and its ligand R-spondin 3 in the regulation of postmitotic neurons.

\section{References}

Baker H, Morel K, Stone DM, Maruniak JA (1993) Adult naris closure profoundly reduces tyrosine hydroxylase expression in mouse olfactory bulb. Brain Res 614:109-116. CrossRef Medline

Banerjee A, Marbach F, Anselmi F, Koh MS, Davis MB, Garcia da Silva P, Delevich K, Oyibo HK, Gupta P, Li B, Albeanu DF (2015) An interglomerular circuit gates glomerular output and implements gain control in the mouse olfactory bulb. Neuron 87:193-207. CrossRef Medline

Barker N, van Es JH, Kuipers J, Kujala P, van den Born M, Cozijnsen M, Haegebarth A, Korving J, Begthel H, Peters PJ, Clevers H (2007) Identification of stem cells in small intestine and colon by marker gene Lgr5. Nature 449:1003-1007. CrossRef Medline

Barker N, Huch M, Kujala P, van de Wetering M, Snippert HJ, van Es JH, Sato T, Stange DE, Begthel H, van den Born M, Danenberg E, van den Brink S, Korving J, Abo A, Peters PJ, Wright N, Poulsom R, Clevers H (2010) Lgr5(+ve) stem cells drive self-renewal in the stomach and build longlived gastric units in vitro. Cell Stem Cell 6:25-36. CrossRef Medline

Barker N, Rookmaaker MB, Kujala P, Ng A, Leushacke M, Snippert H, van de Wetering M, Tan S, Van Es JH, Huch M, Poulsom R, Verhaar MC, Peters PJ, Clevers H (2012) Lgr5(+ve) stem/progenitor cells contribute to nephron formation during kidney development. Cell Rep 2:540-552. CrossRef Medline

Batista-Brito R, Close J, Machold R, Fishell G (2008) The distinct temporal origins of olfactory bulb interneuron subtypes. J Neurosci 28:3966-3975. CrossRef Medline

Bramhall NF, Shi F, Arnold K, Hochedlinger K, Edge AS (2014) Lgr5positive supporting cells generate new hair cells in the postnatal cochlea. Stem Cell Rep 2:311-322. CrossRef Medline

Brown JP, Couillard-Després S, Cooper-Kuhn CM, Winkler J, Aigner L, Kuhn HG (2003) Transient expression of doublecortin during adult neurogenesis. J Comp Neurol 467:1-10. CrossRef Medline

Carmon KS, Gong X, Lin Q, Thomas A, Liu Q (2011) R-spondins function as ligands of the orphan receptors LGR4 and LGR5 to regulate Wnt/betacatenin signaling. Proc Natl Acad Sci U S A 108:11452-11457. CrossRef Medline

Cave JW, Baker H (2009) Dopamine systems in the forebrain. Adv Exp Med Biol 651:15-35. CrossRef Medline

Chen M, Tian S, Yang X, Lane AP, Reed RR, Liu H (2014) Wnt-responsive Lgr5(+) globose basal cells function as multipotent olfactory epithelium progenitor cells. J Neurosci 34:8268-8276. CrossRef Medline

Couillard-Despres S, Winner B, Schaubeck S, Aigner R, Vroemen M, Weidner N, Bogdahn U, Winkler J, Kuhn HG, Aigner L (2005) Doublecortin expression levels in adult brain reflect neurogenesis. Eur J Neurosci 21:1-14. CrossRef Medline

de Lau W, Barker N, Low TY, Koo BK, Li VS, Teunissen H, Kujala P, Haegebarth A, Peters PJ, van de Wetering M, Stange DE, van Es JE, Guardavaccaro D, Schasfoort RB, Mohri Y, Nishimori K, Mohammed S, Heck AJ, Clevers H (2011) Lgr5 homologues associate with Wnt receptors and mediate R-spondin signalling. Nature 476:293-297. CrossRef Medline

de Lau W, Peng WC, Gros P, Clevers H (2014) The R-spondin/Lgr5/Rnf43 module: regulator of Wnt signal strength. Genes Dev 28:305-316. CrossRef Medline

de Visser KE, Ciampricotti M, Michalak EM, Tan DW, Speksnijder EN, Hau CS, Clevers H, Barker N, Jonkers J (2012) Developmental stage-specific contribution of LGR5 $(+)$ cells to basal and luminal epithelial lineages in the postnatal mammary gland. J Pathol 228:300-309. CrossRef Medline

Dickins EM, Salinas PC (2013) Wnts in action: from synapse formation to synaptic maintenance. Front Cell Neurosci 7:162. CrossRef Medline

Fleming MS, Ramos D, Han SB, Zhao J, Son YJ, Luo W (2012) The majority of dorsal spinal cord gastrin releasing peptide is synthesized locally 
whereas neuromedin B is highly expressed in pain- and itch-sensing somatosensory neurons. Mol Pain 8:52. CrossRef Medline

Glinka A, Dolde C, Kirsch N, Huang YL, Kazanskaya O, Ingelfinger D, Boutros M, Cruciat CM, Niehrs C (2011) LGR4 and LGR5 are $\mathrm{R}$-spondin receptors mediating Wnt/beta-catenin and Wnt/PCP signalling. EMBO Rep 12:1055-1061. CrossRef Medline

Hirata-Tominaga K, Nakamura T, Okumura N, Kawasaki S, Kay EP, Barrandon Y, Koizumi N, Kinoshita S (2013) Corneal endothelial cell fate is maintained by LGR5 through the regulation of hedgehog and Wnt pathway. Stem Cells 31:1396-1407. CrossRef Medline

Imamura F, Nagao H, Naritsuka H, Murata Y, Taniguchi H, Mori K (2006) A leucine-rich repeat membrane protein, 5T4, is expressed by a subtype of granule cells with dendritic arbors in specific strata of the mouse olfactory bulb. J Comp Neurol 495:754-768. CrossRef Medline

Jaks V, Barker N, Kasper M, van Es JH, Snippert HJ, Clevers H, Toftgård R (2008) Lgr5 marks cycling, yet long-lived, hair follicle stem cells. Nat Genet 40:1291-1299. CrossRef Medline

Kiyokage E, Pan YZ, Shao Z, Kobayashi K, Szabo G, Yanagawa Y, Obata K, Okano H, Toida K, Puche AC, Shipley MT (2010) Molecular identity of periglomerular and short axon cells. J Neurosci 30:1185-1196. CrossRef Medline

Kosaka T, Kosaka K (2011) "Interneurons" in the olfactory bulb revisited. Neurosci Res 69:93-99. CrossRef Medline

Kosaka T, Komada M, Kosaka K (2008) Sodium channel cluster, betaIVspectrin and ankyrinG positive "hot spots" on dendritic segments of parvalbumin-containing neurons and some other neurons in the mouse and rat main olfactory bulbs. Neurosci Res 62:176-186. CrossRef Medline

Lein ES, Hawrylycz MJ, Ao N, Ayres M, Bensinger A, Bernard A, Boe AF, Boguski MS, Brockway KS, Byrnes EJ, Chen L, Chen L, Chen TM, Chin MC, Chong J, Crook BE, Czaplinska A, Dang CN, Datta S, Dee NR, et al. (2007) Genome-wide atlas of gene expression in the adult mouse brain. Nature 445:168-176. CrossRef Medline

Lepousez G, Nissant A, Lledo PM (2015) Adult neurogenesis and the future of the rejuvenating brain circuits. Neuron 86:387-401. CrossRef Medline

Leushacke M, Ng A, Galle J, Loeffler M, Barker N (2013) Lgr5(+) gastric stem cells divide symmetrically to effect epithelial homeostasis in the pylorus. Cell Rep 5:349-356. CrossRef Medline

Liu S, Puche AC, Shipley MT (2016) The interglomerular circuit potently inhibits olfactory bulb output neurons by both direct and indirect pathways. J Neurosci 36:9604-9617. CrossRef Medline

Lledo PM, Merkle FT, Alvarez-Buylla A (2008) Origin and function of olfactory bulb interneuron diversity. Trends Neurosci 31:392-400. CrossRef Medline

McQuiston AR, Katz LC (2001) Electrophysiology of interneurons in the glomerular layer of the rat olfactory bulb. J Neurophysiol 86:1899-1907. Medline

Miller TE, Wang J, Sukhdeo K, Horbinski C, Tesar PJ, Wechsler-Reya RJ, Rich JN (2014) Lgr5 marks post-mitotic, lineage restricted cerebellar granule neurons during postnatal development. PLoS One 9:e114433. CrossRef Medline

Ming GL, Song H (2011) Adult neurogenesis in the mammalian brain: sig- nificant answers and significant questions. Neuron 70:687-702. CrossRef Medline

Mullen RJ, Buck CR, Smith AM (1992) NeuN, a neuronal specific nuclear protein in vertebrates. Development 116:201-211. Medline

Nacher J, Crespo C, McEwen BS (2001) Doublecortin expression in the adult rat telencephalon. Eur J Neurosci 14:629-644. CrossRef Medline

Ng A, Tan S, Singh G, Rizk P, Swathi Y, Tan TZ, Huang RY, Leushacke M, Barker N (2014) Lgr5 marks stem/progenitor cells in ovary and tubal epithelia. Nat Cell Biol 16:745-757. CrossRef Medline

Parrish-Aungst S, Shipley MT, Erdelyi F, Szabo G, Puche AC (2007) Quantitative analysis of neuronal diversity in the mouse olfactory bulb. J Comp Neurol 501:825-836. CrossRef Medline

Plaks V, Brenot A, Lawson DA, Linnemann JR, Van Kappel EC, Wong KC, de Sauvage F, Klein OD, Werb Z (2013) Lgr5-expressing cells are sufficient and necessary for postnatal mammary gland organogenesis. Cell Rep 3:70-78. CrossRef Medline

Purro SA, Galli S, Salinas PC (2014) Dysfunction of Wnt signaling and synaptic disassembly in neurodegenerative diseases. J Mol Cell Biol 6:75-80. CrossRef Medline

Shi F, Kempfle JS, Edge AS (2012) Wnt-responsive Lgr5-expressing stem cells are hair cell progenitors in the cochlea. J Neurosci 32:9639-9648. CrossRef Medline

Shi F, Hu L, Edge AS (2013) Generation of hair cells in neonatal mice by beta-catenin overexpression in Lgr5-positive cochlear progenitors. Proc Natl Acad Sci U S A 110:13851-13856. CrossRef Medline

Sukhdeo K, Koch CE, Miller TE, Zhou H, Rivera M, Yan K, Cepko CL, Lathia JD, Rich JN (2014) The Lgr5 transgene is expressed specifically in glycinergic amacrine cells in the mouse retina. Exp Eye Res 119:106-110. CrossRef Medline

Sun X, Terakawa J, Clevers H, Barker N, Daikoku T, Dey SK (2014) Ovarian LGR5 is critical for successful pregnancy. FASEB J 28:2380-2389. CrossRef Medline

Sunkin SM, Ng L, Lau C, Dolbeare T, Gilbert TL, Thompson CL, Hawrylycz M, Dang C (2013) Allen Brain Atlas: an integrated spatio-temporal portal for exploring the central nervous system. Nucleic Acids Res 41:D996D1008. CrossRef Medline

Tian H, Biehs B, Warming S, Leong KG, Rangell L, Klein OD, de Sauvage FJ (2011) A reserve stem cell population in small intestine renders Lgr5positive cells dispensable. Nature 478:255-259. CrossRef Medline

Whitesell JD, Sorensen KA, Jarvie BC, Hentges ST, Schoppa NE (2013) Interglomerular lateral inhibition targeted on external tufted cells in the olfactory bulb. J Neurosci 33:1552-1563. CrossRef Medline

Whitman MC, Greer CA (2009) Adult neurogenesis and the olfactory system. Prog Neurobiol 89:162-175. CrossRef Medline

Yee KK, Li Y, Redding KM, Iwatsuki K, Margolskee RF, Jiang P (2013) Lgr5EGFP marks taste bud stem/progenitor cells in posterior tongue. Stem Cells 31:992-1000. CrossRef Medline

Yoshihara S, Takahashi H, Nishimura N, Naritsuka H, Shirao T, Hirai H, Yoshihara Y, Mori K, Stern PL, Tsuboi A (2012) 5T4 glycoprotein regulates the sensory input-dependent development of a specific subtype of newborn interneurons in the mouse olfactory bulb. J Neurosci 32:22172226. CrossRef Medline 